\title{
Augmented Post-Induction Therapy for Children with High-Risk Acute Lymphoblastic Leukemia and a Slow Response to Initial Therapy
}

\author{
Rahman ATMA, Gupta SK, Mannan MA, Nahar K
}

Department of Paediatric Haematology and Oncology

Bangabandhu Sheikh Mujib Medical University

Shahbagh, Dhaka, Bangladesh

\section{Corresponding Author}

Shyam Kumar Gupta

Department of Paediatric Haematology and Oncology

Bangabandhu Sheikh Mujib Medical University

Shahbagh, Dhaka, Bangladesh

E-mail: docsrun@gmail.com

\section{Citation}

Rahman ATMA, Gupta SK, Mannan MA, Nahar K. Augmented Post-Induction Therapy for Children with High-Risk Acute Lymphoblastic Leukemia and a Slow Response to Initial Therapy. Kathmandu Univ med J 2012;10(3):53-59.

\begin{abstract}
Background

Children with high-risk acute lymphoblastic leukemia (ALL) who have a slow response to initial chemotherapy (more than 25 percent blasts in the bone marrow on day 7) have a poor outcome despite intensive therapy. We conducted a randomized trial in which such patients were treated with either an augmented intensive regimen of post-induction chemotherapy or a standard regimen of intensive post-induction chemotherapy.
\end{abstract}

\section{Objective}

To compare the effect of augmented therapy with standard intensive post induction therapy in children with high-risk ALL who entered remission after a slow response to initial therapy.

\section{Methods}

Between January 2005 and December 2011, 311 children with newly diagnosed ALL who were either 1 to 9 years of age with white cell counts of at least 50,000 per cubic millimeter or 10 years of age or older, had a slow response to initial therapy, and entered remission at the end of induction chemotherapy were randomly assigned to receive standard therapy (156 children) or augmented therapy (155). Those with lymphomatous features were excluded. Event-free survival and overall survival were assessed from the end of induction treatment.

\section{Results}

The outcome at five years was significantly better in the augmented-therapy group than in the standard-therapy group. The difference between treatments was most pronounced among patients one to nine years of age, all of whom had white-cell counts of at least 50,000 per cubic millimeter $(P<0.001)$. Risk factors for an adverse event in the entire cohort included a white-cell count of 200,000 per cubic millimeter or higher $(\mathrm{P}=0.004)$. The toxic effects of augmented therapy were considerable but manageable.

\section{Conclusion}

Augmented post-induction chemotherapy results in an excellent outcome for most patients with high-risk ALL and a slow response to initial therapy.

\section{KEY WORDS}

Augmented post induction therapy, leukemia

\section{INTRODUCTION}

In children with acute lymphoblastic leukemia (ALL) who bear certain presenting features, such as a white cell count above 50,000 per cubic millimeter an age of 10 years or older, the presence of bulky disease, T-celllineage immunophenotype and various chromosomal translocations carry an increased risk of treatment failure..$^{1-5}$ The outcome for most of these children has improved with the use of intensive chemotherapy after the induction of remission, but approximately 30 percent of such high-risk patients eventually relapse. . $^{5-8}$

Numerous studies have demonstrated that a rapid response to initial chemotherapy is an important prognostic factor in childhood ALL. ${ }^{6-9}$ German investigators observed that patients with fewer than 1000 blasts per cubic millimeter in the peripheral blood after a seven-day 


\begin{tabular}{|c|c|c|c|c|c|}
\hline \multicolumn{3}{|c|}{ Standard THERAPY } & \multicolumn{3}{|c|}{ Augmented Therapy } \\
\hline PHASE & TREATMENT & DOSE & PHASE & TREATMENT & DosE \\
\hline $\begin{array}{l}\text { Consolidat ion } \\
(5 \mathrm{wk})\end{array}$ & $\begin{array}{l}\text { Prednisone } \\
\text { Cydophosphamide } \\
\text { Mercaptopurine } \\
\text { Vin cristine } \\
\text { Cytarabine } \\
\text { Methotrexate† } \\
\text { Radiotherapy } \ddagger\end{array}$ & $\begin{array}{l}7.5 \mathrm{mg} / \mathrm{m}^{2} \text { day } 0 ; 3.75 \\
\mathrm{mg} / \mathrm{m}^{2} / \mathrm{d} \text { ay days } 1,2 \\
1000 \mathrm{mg} / \mathrm{m}^{2} / \text { day IV days } 0,14 \\
60 \mathrm{mg} / \mathrm{m}^{2} / \text { day PO days } 0-27 \\
1.5 \mathrm{mg} / \mathrm{m}^{2} / \text { day IV days } 14,21, \\
42,49 \\
75 \mathrm{mg} / \mathrm{m}^{2} / \text { day IV days } 1-4, \\
8-11,15-18,22-25 \\
\text { IT days } 1,8,15,22 \\
\text { Cranial, } 1800 \mathrm{cGy} \\
\text { Cranial, } 2400 \mathrm{cGy} \text {, and } \\
\text { spinal, } 600 \mathrm{cGy}\end{array}$ & $\begin{array}{l}\text { Consolidat ion } \\
(9 \mathrm{wk})\end{array}$ & $\begin{array}{l}\text { Cyclophosphamide } \\
\text { Cytarabine } \\
\text { Mercaptopurine } \\
\text { Vin cristine } \\
\text { Asparaginase }\end{array}$ & $\begin{array}{l}1000 \mathrm{mg} / \mathrm{m}^{2} / \text { day IV days } 0,28 \\
75 \mathrm{mg} / \mathrm{m}^{2} / \text { day } \mathrm{SQ} \text { or IV days } \\
1-4,8-11,29-32,36-39 \\
60 \mathrm{mg} / \mathrm{m}^{2} / \text { day PO days } 0-13 \text {, } \\
28-41 \\
1.5 \mathrm{mg} / \mathrm{m}^{2} / \text { day IV days } 14,21 \text {, } \\
42,49 \\
6000 \mathrm{U} / \mathrm{m}^{2} / \text { day IM days } 14,16 \text {, } \\
18,21,23,25,42,44,46,49, \\
51,53 \\
\text { IT days } 1,8,15,22 \\
\text { Cranial }, 1800 \mathrm{cGy} \\
\text { Cranial, } 2400 \mathrm{cGy} \text {, and } \\
\text { spinal, } 600 \mathrm{cGy} \\
\text { Testicular, } 2400 \mathrm{cGy}\end{array}$ \\
\hline $\begin{array}{c}\text { Interim mainte- } \\
\text { nance ( } 8 \mathrm{wk})\end{array}$ & $\begin{array}{l}\text { Mercaptopurine } \\
\text { Methotrexate }\end{array}$ & $\begin{array}{l}60 \mathrm{mg} / \mathrm{m}^{2} / \text { day PO days } 0-41 \\
15 \mathrm{mg} / \mathrm{m}^{2} / \text { day PO days } 0,7 \\
14,21,28,35\end{array}$ & $\begin{array}{l}\text { Interim mainte- } \\
\text { nance I ( } 8 \text { wk) }\end{array}$ & $\begin{array}{l}\text { Vincristine } \\
\text { Methotrexate } \\
\text { Asparaginase }\end{array}$ & $\begin{array}{l}1.5 \mathrm{mg} / \mathrm{m}^{2} / \text { day IV days } 0,10, \\
20,30,40 \\
100 \mathrm{mg} / \mathrm{m}^{2} / \text { day IV days } 0,10, \\
20,30,40 \text { (escalate by } 50 \\
\mathrm{mg} / \mathrm{m}^{2} / \text { dose) } \\
15,000 \mathrm{U} / \mathrm{m}^{2} / \text { day IM days } 1,11, \\
21,31,41\end{array}$ \\
\hline $\begin{array}{l}\text { Delayed intensifi- } \\
\text { cation ( } 7 \text { wk) }\end{array}$ & & & $\begin{array}{l}\text { Delayed intensifi- } \\
\text { cation I ( } 8 \mathrm{wk})\end{array}$ & & \\
\hline $\begin{array}{l}\text { Reinduction } \\
\qquad(4 \mathrm{wk})\end{array}$ & $\begin{array}{l}\text { Dexamethasone } \\
\text { Vin cristine } \\
\text { Doxorubicin } \\
\text { Asparaginase }\end{array}$ & $\begin{array}{l}10 \mathrm{mg} / \mathrm{m}^{2} / \text { day PO days } 0-20 \\
\text { then taper for } 7 \text { days } \\
1.5 \mathrm{mg} / \mathrm{m}^{2} / \text { day IV days } 0,14,21 \\
25 \mathrm{mg} / \mathrm{m}^{2} / \text { day IV days } 0,7,14 \\
6000 \mathrm{U} / \mathrm{m}^{2} / \text { day IM days } 3,5,7 \text {, } \\
10,12,14\end{array}$ & $\begin{array}{l}\text { Reinduction } \\
\quad(4 \mathrm{wk})\end{array}$ & $\begin{array}{l}\text { Dexamethasone } \\
\text { Vincristine } \\
\text { Doxorubicin } \\
\text { Asparaginase }\end{array}$ & $\begin{array}{l}10 \mathrm{mg} / \mathrm{m}^{2} / \text { day PO days } 0-20, \\
\text { then taper for } 7 \text { days } \\
1.5 \mathrm{mg} / \mathrm{m}^{2} / \text { day IV days } 0,14,21 \\
25 \mathrm{mg} / \mathrm{m}^{2} / \text { day IV days } 0,7,14 \\
6000 \mathrm{U} / \mathrm{m}^{2} / \text { day IM days } 3,5,7 \text {, } \\
10,12,14\end{array}$ \\
\hline $\begin{array}{l}\text { Recon solid ation } \\
\text { (3 wk) }\end{array}$ & $\begin{array}{l}\text { Vincristine } \\
\text { Cyclophosphamide } \\
\text { Thioguanine } \\
\text { Cytarabine } \\
\text { Methotrexate† }\end{array}$ & $\begin{array}{l}1.5 \mathrm{mg} / \mathrm{m}^{2} / \text { day IV days } 42,49 \\
1000 \mathrm{mg} / \mathrm{m}^{2} \text { IV day } 28 \\
60 \mathrm{mg} / \mathrm{m}^{2} / \text { day PO days } 28-41 \\
75 \mathrm{mg} / \mathrm{m}^{2} / \text { day SQ or IV days } \\
29-32,36-39 \\
\text { IT days } 29,36\end{array}$ & $\begin{array}{l}\text { Reconsolidation } \\
\quad(4 \mathrm{wk})\end{array}$ & $\begin{array}{l}\text { Vincristine } \\
\text { Cyclophosphamide } \\
\text { Thioguanine } \\
\text { Cytarabine } \\
\text { Methotrexatef } \\
\text { Asparaginase }\end{array}$ & $\begin{array}{l}1.5 \mathrm{mg} / \mathrm{m}^{2} / \text { day IV days } 42,49 \\
1000 \mathrm{mg} / \mathrm{m}^{2} \text { IV day } 28 \\
60 \mathrm{mg} / \mathrm{m}^{2} / \text { day PO days } 28-41 \\
75 \mathrm{mg} / \mathrm{m}^{2} / \text { day SQ or IV days } \\
29-32,36-39 \\
\text { IT days } 29,36 \\
6000 \mathrm{U} / \mathrm{m}^{2} / \text { day IM days } 42 \\
44,46,49,51,53\end{array}$ \\
\hline $\begin{array}{l}\text { Maintenance } \\
(12 \mathrm{wk}) \S\end{array}$ & $\begin{array}{l}\text { Vincristine } \\
\text { Prednisone } \\
\text { Mercaptopurine } \\
\text { Methotrexate } \\
\text { Methotrexatef }\end{array}$ & $\begin{array}{l}1.5 \mathrm{mg} / \mathrm{m}^{2} / \text { day IV days } 0, \\
28,56 \\
40 \mathrm{mg} / \mathrm{m}^{2} / \text { day PO days } 0-4, \\
28-32,56-60 \\
75 \mathrm{mg} / \mathrm{m}^{2} / \text { day PO days } 0-83 \\
20 \mathrm{mg} / \mathrm{m}^{2} / \text { day PO days } 7,14,21, \\
28,35,42,49,56,63,70,77 \\
\text { IT day } 0\end{array}$ & $\begin{array}{l}\text { Interim mainte- } \\
\text { nance II (8 wk) }\end{array}$ & $\begin{array}{l}\text { Vincristine } \\
\text { Methotrexate }\end{array}$ & $\begin{array}{l}1.5 \mathrm{mg} / \mathrm{m}^{2} / \text { day IV days } 0,10, \\
20,30,40 \\
100 \mathrm{mg} / \mathrm{m}^{2} / \text { day IV days } 0,10, \\
20,30,40 \text { (escalate by } 50 \\
\mathrm{mg} / \mathrm{m}^{2} / \text { dose) } \\
15,000 \mathrm{U} / \mathrm{m}^{2} / \text { day IM days } 1,11, \\
21,31,41 \\
\text { IT days } 0,20,40\end{array}$ \\
\hline & & & $\begin{array}{l}\text { Delayed intensifi- } \\
\text { cation II ( } 8 \mathrm{wk})\end{array}$ & $\begin{array}{l}\text { Same as for delayed } \\
\text { intensification I }\end{array}$ & \\
\hline & & & $\begin{array}{l}\text { Maintenance } \\
\qquad(12 \mathrm{wk}) \S\end{array}$ & $\begin{array}{l}\text { Vincristine } \\
\text { Prednisone } \\
\text { Mercaptopurine } \\
\text { Methotrexate } \\
\text { Methotrexate }\end{array}$ & $\begin{array}{l}1.5 \mathrm{mg} / \mathrm{m}^{2} / \text { day IV days } 0,28,56 \\
60 \mathrm{mg} / \mathrm{m}^{2} / \text { day PO days } 0-4, \\
28-32,56-60 \\
75 \mathrm{mg} / \mathrm{m}^{2} / \text { day PO days } 0-83 \\
20 \mathrm{mg} / \mathrm{m}^{2} / \text { day PO days } 7,14, \\
21,28,35,42,49,56,63, \\
70,77 \\
\text { IT day } 0\end{array}$ \\
\hline
\end{tabular}

*IV denotes intravenously, PO orally, IT intrathecally, SQ subcutaneously, and IM intramuscularly.

†The doses were age-adjusted as follows: age 1 to 1.9 years, $8 \mathrm{mg}$; age 2 to 2.9 years, $10 \mathrm{mg}$; age $\geqslant 3$ years, $12 \mathrm{mg}$. Patients with central nervous system disease at diagnosis did not receive intrathecal methotrexate on days 15 and 22 of consolidation therapy.

$\ddagger$ During the first two weeks of consolidation therapy, patients without central nervous system disease at diagnosis received 1800 cGy of cranial radiotherapy in 10 fractions; patients with central nervous system disease at diagnosis received 2400 cGy to the cranial midplane in 12 fractions and 600 cGy to the spinal cord in 3 fractions. In the augmented-therapy group, patients with testiculomegaly at diagnosis received 2400 cGy bilateral testicular radiation in 8 fractions.

\$The cycles of mainten ance therapy were repeated until the total duration of therapy, beginning with the first interim maintenance period, reached two years for girls and three years for boys.

Figure 1. The standard therapy and augmented therapy regimen.

course of prednisone had significantly better event free survival than patients with 1000 or more blasts per cubic millimeter. ${ }^{10,11}$ Similarly, it is reported that children with $25 \%$ blasts or fewer in the bone marrow on day seven had a better response to initial chemotherapy (three-year eventfree survival, $77 \%$ ) than those with more than $25 \%$ blasts (three-year event-free survival, 48\%). ${ }^{11}$ In an attempt to improve the outcome for children with a slow response to initial therapy, we follow a strategy of augmented, intensive post-induction chemotherapy that was based on previous successful regimens for ALL. ${ }^{6,12,13}$ This approach appeared promising in a nonrandomized pilot study. We now report 
on a randomized comparison of augmented therapy with standard intensive post induction therapy in children with high-risk ALL who entered remission after a slow response to initial therapy.

\section{METHODS}

\section{Patients}

Children with newly diagnosed ALL who were one to nine years of age and had white cell counts of at least 50,000 per cubic millimeter or who were 10 years of age or older were enrolled between January 2005 and December 2011. Those with lymphomatous features were excluded. Diagnosis was based on morphologic, biochemical, and immunologic features of leukemic cells, including lymphoblast morphology as determined by Wright Giemsa staining, negative staining for myeloperoxidase, and reactivity with monoclonal antibodies to lymphoid differentiation antigens associated with B-cell or T-cell lineage, Patients with slow initial responses (more than $25 \%$ marrow blasts on day seven) who had entered remission by day 28 were randomly assigned at the end of induction therapy to receive standard or augmented therapy.

\section{Treatment Protocol}

All patients received identical five week courses of induction chemotherapy, withUK-ALLX1 protocol. The post induction regimens are with Standard therapy and Augmented Berlin Frankfurt Munster therapy given (Fig 1). ${ }^{14,15}$ Therapy was continued for two years for girls and for three years for boys, beginning with the first interim maintenance period (Fig 1). Pre-symptomatic central nervous system therapy consisted of intrathecal methotrexate and cranial radiation. Informed consent was obtained from the patients, their parents, or both, as deemed appropriate, according to rules of the University.

\section{Study Design and Statistical Analysis}

Balanced block randomization was used to ensure that approximately equal numbers of patients were randomly assigned to each regimen. The study was monitored by an independent data monitoring committee and followed a monitoring plan that was based on group sequential monitoring boundaries that required analysis of results at six month intervals for a maximum of 10 analyses. ${ }^{16}$ With a target enrollment of 296 randomized patients, we estimated that the study had a power of approximately 81 percent at the final analysis to detect a change in five year event free survival from $45 \%$ to $62 \%$ or more with a two sided log rank test (alpha level, 0.05).

Similarities between patients in the two groups were assessed with chi square tests for homogeneity of proportions. Outcome analyses used life table methods and associated statistics. The primary end point examined was event free survival from the time of randomization. The events considered were relapse at any site, death during remission, or a second malignant neoplasm, which ever occurred first. Data on patients who had not had an event at the time of the analysis were censored in the analysis of event free survival at the time of last contact with them. Life table estimates were calculated by Kaplan-Meier procedure, and the standard deviation of the life table estimate was obtained with Greenwood's formula. ${ }^{17}$ The Kaplan-Meier estimates ( \pm SD) are presented for either the first five years or the first three years after randomization, depending on the number of patients in follow up. Ninety five percent confidence intervals can be approximated as the life table estimates \pm 1.96 SD. The log rank statistic was used to compare patterns of event free survival and overall survival in the groups. ${ }^{18,19}$ Comparisons of randomized treatment regimens were performed according to the intention to treat method. Stratified log rank tests were also used to adjust for the possible modifying effect of other factors on the comparison of interest. ${ }^{20}$ An adjusted Cox regression analysis was used to determine the influence of prognostic factors on the primary treatment effect. Life table analyses of the effect of isolated central nervous system and marrow relapses on the results with each regimen were compared with the log rank statistic. Life table analysis of the relative risk of an adverse event was calculated with the log rank ratio of observed events to expected events. ${ }^{21}$

\section{RESULTS}

\section{Patients}

A total of 1136 patients were enrolled. Three patients died before day seven, and marrow was not obtained on day seven from 15 patients. Of the remaining 1118 patients, 360 (32\%) had slow responses to initial therapy. Of these,

Table 1. Characteristics of the patients at diagnosis.

\begin{tabular}{|c|c|c|c|c|}
\hline $\begin{array}{l}\text { CHARAC- } \\
\text { TERISTIC }\end{array}$ & $\begin{array}{l}\text { STANDARD } \\
\text { THERAPY } \\
(\mathrm{N}=156) \\
\text { no. }(\%)\end{array}$ & $\begin{array}{l}\text { AUG- } \\
\text { MENTED } \\
\text { THERAPY } \\
\text { (N=155) } \\
\text { no. }(\%)\end{array}$ & P VALUE & $\begin{array}{l}\text { CHARAC- } \\
\text { TERISTIC }\end{array}$ \\
\hline Age (years) & & & 0.85 & $\begin{array}{l}\text { Hemoglo- } \\
\text { bin (g/dl) }\end{array}$ \\
\hline 1-9 & $50(32.1)$ & $54(34.8)$ & & $1-7.9$ \\
\hline $10-15$ & $73(46.8)$ & 68 (43.9) & & $8.0-10.9$ \\
\hline$\geq 16$ & $33(21.2)$ & $33(21.3)$ & & $\geq 11.0$ \\
\hline $\begin{array}{l}\text { White cells } \\
(\times 10-3 / \\
\mathrm{mm} 3)\end{array}$ & & & 0.53 & $\begin{array}{l}\text { Platelets } \\
(\times 10-3 / \\
\mathrm{mm} 3)\end{array}$ \\
\hline$<50$ & 79 (50.6) & $76(49.0)$ & & $1-49$ \\
\hline 50-199 & $59(37.8)$ & $66(42.6)$ & & $50-149$ \\
\hline$\geq 200$ & $18(11.5)$ & $13(8.4)$ & & $\geq 150$ \\
\hline Sex & & & 0.61 & $\begin{array}{l}\text { CNS } \\
\text { disease at } \\
\text { diagnosis }\end{array}$ \\
\hline Male & 89 (57.1) & $83(53.5)$ & & Yes \\
\hline
\end{tabular}


340 (94\%) entered remission after induction therapy, 19 did not enter remission after induction therapy, and one received modified induction therapy and therefore was deemed ineligible. Of the 340 eligible patients, 317 (93\%) underwent randomization. A subsequent review revealed that six of these patients did not have a slow response; thus, 311 patients were eligible for the study. Of these, 156 were assigned to standard therapy and 155 were assigned to augmented therapy.

The characteristics of the patients in the two groups are shown in Table 1 . There were no significant differences between the groups. Most patients were at least 10 years of age, and approximately half had white cell counts of at least 50,000 per cubic millimeter. Among 209 patients with immunophenotypic data, $87.6 \%$ had ALL of B cell lineage.

\section{Outcome of Treatment}

The four year event free survival rate was significantly better among patients in augmented therapy group than among those in standard therapy group ( $75.4 \pm 4.0$ vs. $57.2 \pm 4.5 \%$, $\mathrm{P}=0.009$, adjusted for multiple evaluations of the data). At that time the median follow up for patients with event free survival was 31 months (range, 1 to 63). After an additional follow up period of approximately 1.5 years, five year event free survival remained significantly better in the augmented therapy group than in the standard therapy group (75.0 \pm 3.8 vs. $55.0 \pm 4.5$ percent, $P<0.001$ ) (Fig 2 ). The median follow up for patients with event free survival was 49 months (range, 2 to 82 months). The difference in event free survival was maintained $(P<0.001)$ when patients who received a bone marrow transplant were censored at the time of transplantation. Overall survival at five years was also better in the augmented therapy group than in the standard therapy group $(78.4 \pm 3.7$ vs. $66.7 \pm 4.2$ percent, $\mathrm{P}=0.02$ ).

There were 65 events in the standard therapy group and 36 events in the augmented therapy group (Table 2). Isolated marrow relapse was the main cause of treatment failure for both regimens, occurring in 43 patients in the standard therapy group and 30 patients in the augmented therapy group ( $P=0.004$ by the log rank test), whereas central nervous system relapses were more common among patients in the standard therapy group ( 8 vs. $0, P=0.002$ by the log rank test). Seven patients in the standard therapy group and four patients in the augmented therapy group died while in remission.

In all subgroups analyzed, the results were better among patients who received augmented therapy than among those who received standard therapy. The difference in outcome between groups was most pronounced for patients who were one to nine years of age, all of whom had high white cell counts as dictated by the eligibility criteria, with five year event free survival of $41.7 \pm 8.4 \%$ in the standard therapy group and $84.6 \pm 5.0 \%$ in the augmented therapy group $(\mathrm{P}<0.001)$ (Figure 3 ) and a relative risk of an adverse event in the standard therapy group of 4.6. For patients who

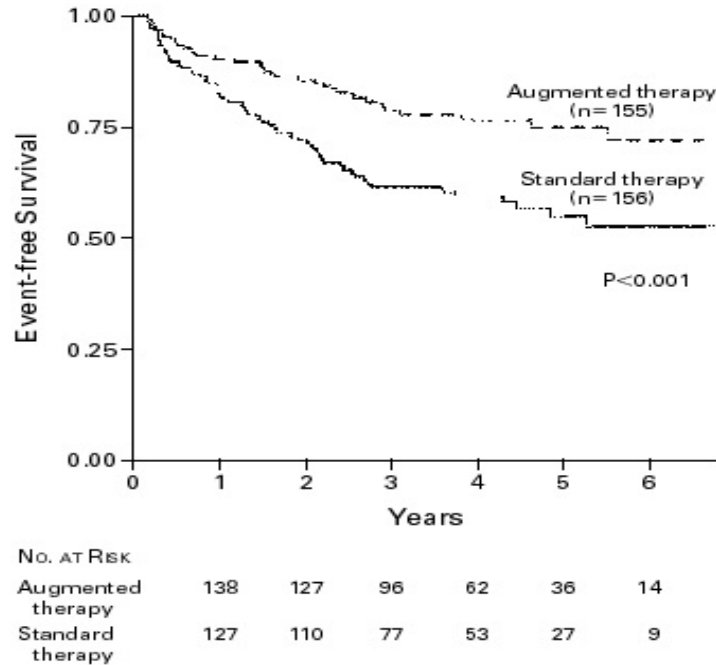

Figure 2. Event free Survival during Five Years of Follow up in Patients with ALL, According to the Type of Post Induction Chemotherapy.

Table 2. Frequency and type of events among patients assigned to standard or augmented therapy.

\begin{tabular}{lll} 
Event & $\begin{array}{l}\text { Standard Therapy } \\
(\mathrm{N}=156) \mathrm{n}(\%)\end{array}$ & $\begin{array}{l}\text { Augmented Therapy } \\
(\mathrm{n}=155) \mathrm{n}(\%)\end{array}$ \\
$\begin{array}{lll}\text { Isolated marrow relapse } & 43(27.6) & 30(19.4)\end{array}$ \\
$\begin{array}{l}\text { Central nervous system } \\
\text { relapse }\end{array}$ & $8(5.1)$ & 0 \\
$\begin{array}{l}\text { Marrow and central ner- } \\
\text { vous system relapse }\end{array}$ & $3(1.9)$ & $1(0.6)$ \\
$\begin{array}{l}\text { Testicular relapse } \\
\text { Marrow and testicular }\end{array}$ & $2(1.3)$ & 0 \\
relapse & $1(0.6)$ & 0 \\
Relapse at other sites & $1(0.6)$ & 0 \\
\hline Second cancer & 0 & $1(0.6)$ \\
Death in remission * & $7(4.5)$ & $4(2.6)$ \\
\hline $\begin{array}{l}\text { Total } \\
\text { R }\end{array}$ & $65(41.7)$ & $36(23.2)$
\end{tabular}

*All but two deaths were related to the toxicity of treatment

were 10 or more years old with white cell counts of at least 50,000 per cubic millimeter, the outcome was better after augmented therapy than after standard therapy (three year event free survival, $66.7 \pm 9.7$ vs. $47.9 \pm 9.7 \%$ ) (Figure 3 ), with a relative risk of an adverse event of 1.7 in the standard therapy group $(P=0.21)$. Among patients who were 10 or more years old with white cell counts below 50,000 per cubic millimeter, the five year event free survival rate was $73.3 \pm 5.7 \%$ in the augmented therapy group and $66.2 \pm 5.8 \%$ in the standard therapy group (relative risk of an adverse event, 1.26; $\mathrm{P}=0.45$ ). Among 31 patients with white cell counts of 200,000 per cubic millimeter the five year event free survival rate was $73.3 \pm 5.7 \%$ in the augmented therapy group and $66.2 \pm 5.8 \%$ in the standard therapy group (relative risk of an adverse event, 1.26; $\mathrm{P}=0.45$ ). Among 31 patients with white cell counts of 200,000 per cubic millimeter or higher, event free survival was better for those in the augmented therapy group (relative risk of an 


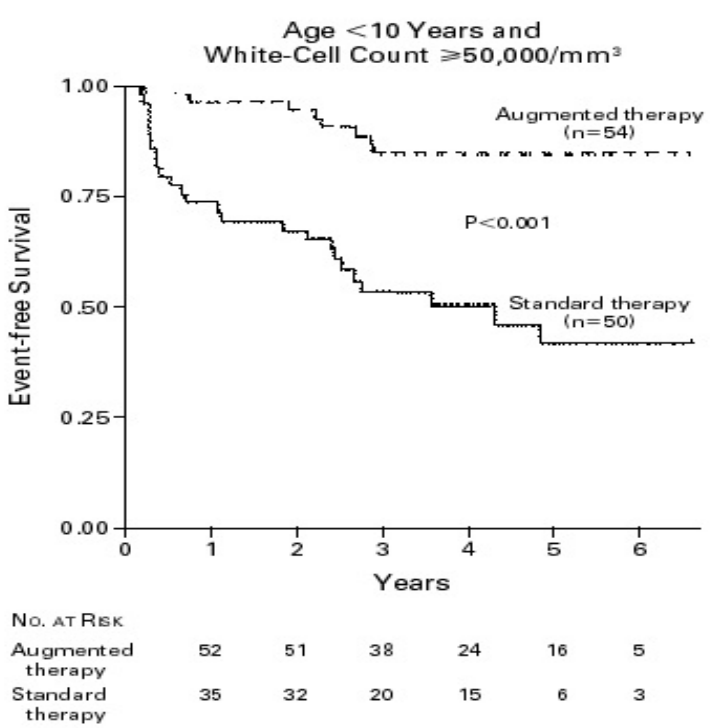

Figure 3. Event free Survival during Five Years of Follow up in Patients with ALL Who Received Standard Therapy or Augmented Therapy, According to Age and White Cell Count at Diagnosis.

adverse event in the standard therapy group, $2.2 ; \mathrm{P}=0.14$ )

Augmented therapy improved the outcome for patients with ALL of either B cell lineage or T cell lineage. Estimates of five year event free survival for patients with B celllineage $A L L$ were $74.7 \pm 5.1$ percent with augmented therapy and $52.2 \pm 5.9$ percent with standard therapy $(P=0.002)$. For patients with T cell-lineage ALL, event free survival at three years was $91.7 \pm 8.0$ percent in the augmented therapy group and $71.4 \pm 12.1$ percent in the standard therapy group $(P=0.25)$. Furthermore, the outcome for patients with ALL of $T$ cell lineage was similar to that for patients with ALL of $B$ cell lineage, regardless of regimen.

\section{Prognostic Factors}

An analysis of prognostic factors for the entire cohort of patients indicated that most base line characteristics did not influence event free survival. However, a white cell count of 200,000 per cubic millimeter or higher, race other than black or white, and the presence of a $t(9 ; 22)$ translocation were prognostically important. For patients with white cell counts of at least 200,000 per cubic millimeter, three year event free survival was $47.4 \pm 9.1 \%$, as compared with $72.4 \pm 2.7 \%$ for those with white cell counts below 200,000 per cubic millimeter $(P=0.004)$. A Cox regression analysis with adjustment for these and other common prognostic factors revealed no attenuation of the effect of treatment on the difference in outcome between the augmented therapy and the standard therapy groups $(P=0.001)$.

\section{Toxic Effects}

The toxic effects of the two types of therapy are shown in Table 3. There was a higher frequency of allergic reactions to Escherichia coli asparaginase in the augmented therapy group than in the standard therapy group (64 vs. 4 reactions). Osteonecrosis developed in 20 patients in the augmented therapy group and in 14 patients in the standard
Table 3. Toxic Effects of standard and augmented therapy.

\begin{tabular}{|c|c|c|}
\hline Toxic Effect & $\begin{array}{l}\text { Standard } \\
\text { Therapy (N=156) } \\
\mathrm{n}(\%)\end{array}$ & $\begin{array}{l}\text { Augmented Thera- } \\
\text { py }(\mathrm{N}=155) \mathrm{n}(\%)\end{array}$ \\
\hline \multicolumn{3}{|c|}{$\begin{array}{l}\text { Allergic reaction to aspara- } \\
\text { ginase }\end{array}$} \\
\hline $\begin{array}{l}\text { Escherchia coli } \\
\text { asparaginase }\end{array}$ & $4(2.6)$ & $64(41.3)$ \\
\hline Erwinia asparaginase & 0 & $15(9.7)^{*}$ \\
\hline $\begin{array}{l}\text { Polyethylene glycol } \\
\text { asparaginase }\end{array}$ & 0 & $2(1.3)^{*}$ \\
\hline Pancreatitis & $2(1.3)$ & $5(3.2)$ \\
\hline Thrombotic events & 0 & $4(2.6)$ \\
\hline Mucositis & 0 & $38(24.5)$ \\
\hline Seizures & $3(1.9)$ & $5(3.2)$ \\
\hline Leukoencephalopathy & $1(0.6)$ & $2(1.3)$ \\
\hline Osteonecrosis & $14(9.0)$ & $20(12.9)$ \\
\hline Stroke & $1(0.6)$ & 0 \\
\hline Death $^{\dagger}$ & $6(3.8)$ & $3(1.9)$ \\
\hline
\end{tabular}

therapy group; only one of these patients was under 10 years of age at the time of diagnosis. Life table estimates for the occurrence of osteonecrosis at three years were $15.1 \%$ for the augmented therapy group and $11.9 \%$ for the standard therapy group $(\mathrm{P}=0.44)$. No cases had developed after three years of follow up. The mean total duration of hospitalization was slightly longer for patients in the augmented therapy group than in the standard therapy group, primarily because of the additional time needed for the second cycles of interim maintenance and delayed intensification therapy (data not shown).

Three patients in the augmented therapy group died in remission as a result of toxicity: one died of acute respiratory distress syndrome, one of pulmonary toxicity, and one of Candida tropicalis infection; one patient in remission was murdered. Seven patients in the standard therapy group died in remission. Four of these deaths were due to documented infection: aspergillosis in one patient, clostridium septicemia in one, hepatosplenic candidiasis in one, and infection with unspecified gram negative bacteria in one. Of the remaining three deaths, one was due to pulmonary hemorrhage, one was due to acute respiratory distress syndrome after a presumed infection, and one was due to unknown causes.

\section{DISCUSSION}

It previously was reported that among children with high risk ALL, those with a rapid response to initial therapy (defined as the presence of no more than $25 \%$ blasts in the marrow on the seventh day of induction chemotherapy) had a better outcome than those with a slow response (more than 25 percent blasts)..$^{9,11,22}$ Other investigators also 
reported poor outcomes for patients with a slow response to prednisone or multiagent induction therapy. ${ }^{6,10,15,23}$ In this randomized trial of post induction treatment of patients with a slow response, we found that the outcome with augmented treatment was superior to that with standard treatment (five year event free survival, $75 \%$ vs. $55 \%$ ). In our nonrandomized pilot study of augmented therapy, the four year event free survival rate $( \pm S D)$ was $70.8 \pm 4.6 \% .{ }^{14}$ Furthermore, subsequent analysis of the pilot study revealed a six year event free survival rate of $65.4 \pm 4.9 \%$, suggesting that the results of the randomized trial are unlikely to change significantly with longer follow up. Our results also suggest that the degree of cytoreduction achieved after one to two weeks of induction chemotherapy is a useful indicator of the susceptibility of leukemic cells to chemotherapeutic drugs. ${ }^{10,15}$

Augmented treatment significantly improved event free survival overall $(75.0 \pm 3.8 \%$, as compared with $55.0 \pm 4.5 \%$ in the standard therapy group). In all subgroups analyzed, augmented therapy resulted in improved event free survival. The difference was significant in the subgroup of patients who were one to nine years of age, all of whom had high white cell counts. There was a trend toward a better outcome among older patients. There was also a trend toward improved outcomes with augmented therapy in patients with ALL of either B cell lineage or T cell lineage. This finding is in agreement with our analysis, which demonstrated improved outcome for the entire cohort of children with T cell-lineage ALL who were treated with Children's Cancer Group protocols between 1989 and 1995. ${ }^{24}$ Augmented therapy was ineffective for the seven patients with the Philadelphia chromosome. Five of these seven patients had events, and four of them ultimately died. The two patients who survived without events received a bone marrow transplant while in first remission. These data are consistent with recent data from European studies of children with ALL who have a poor response to initial prednisone therapy. ${ }^{25}$

The toxic effects of augmented therapy have been considerable, but they appear to be manageable. The most common long term toxic effect was osteonecrosis, which occurred almost exclusively in adolescent patients.

We noted a significantly lower rate of central nervous system relapse in the augmented therapy group than in the standard therapy group. Since the patients assigned to each regimen received cranial radiotherapy and intrathecal therapy for presymptomatic treatment of central nervous system, the benefit observed with augmented therapy may have been due to the use of intensified systemic therapy. Indeed, previous investigators have noted a similar effect with intensive systemic therapy. ${ }^{26-28}$.

Although we do not know which components of augmented therapy were responsible for the improved outcome, we surmise that the effect is attributable to the increased dose intensities and prolonged duration of therapy. During the interim maintenance phase in the augmented therapy regimen, repeated courses of vincristine, intravenous methotrexate, and asparaginase replaced the daily oral mercaptopurine and the weekly oral methotrexate used in the standard therapy regimen. The augmented regimen also included an additional two weeks of nonmyelosuppressive therapy with vincristine and asparaginase during each consolidation or reconsolidation course and included both a second interim maintenance phase and a second course of delayed intensification.

A recent Children's Cancer Group study of intermediate risk ALL showed that patients with a slow response had an improved outcome when treated with two courses of delayed intensification rather than one course, suggesting that prolonged therapy was important to the improved outcome with augmented therapy in the current study. ${ }^{28}$ We are attempting to distinguish the relative contributions of early increased dose intensity and a prolonged duration of therapy in a new therapeutic study of children with high risks ALL.

\section{CONCLUSION}

Augmented post-induction chemotherapy results in an excellent outcome for most patients with high-risk ALL

\section{REFERENCES}

1. Lilleyman JS, Eden OB. United Kingdom Medical Research Council Acute Lymphoblastic Leukaemia (UKALL) Trials I-VIII: clinical features and results of treatment in four groups of children with adverse prognostic features. Med Pediatr Oncol 1986;14:182-186.

2. Hammond $D$, Sather $H$, Nesbit $M$, et al. Analysis of prognostic factors in acute lymphoblastic leukemia. Med Pediatr Oncol 1986;14:124134.

3. Crist W, Boyett J, Pullen J, van Eys J, Vietti T. Clinical and biologic features predict poor prognosis in acute lymphoid leukemias in children and adolescents: a Pediatric Oncology Group review. Med Pediatr Oncol 1986;14:135-139.

4. Steinherz PG, Siegel SE, Bleyer WA, et al. Lymphomatous presentation of childhood acute lymphoblastic leukemia: a subgroup at high risk of early treatment failure. Cancer 1991;68:751-758.

5. Gaynon PS, Bleyer WA, Steinherz PG, et al. Modified BFM therapy for children with previously untreated acute lymphoblastic leukemia and unfavorable prognostic features: report of Children's Cancer Study Group Study CCG-193P. Am J Pediatr Hematol Oncol 1988;10:42-50.

6. Reiter A, Schrappe M, Ludwig WD, et al. Chemotherapy in 998 unselected childhood acute lymphoblastic leukemia patients: results and conclusions of the multicenter trial ALL-BFM 86. Blood 1994;84:3122-3133.

7. Rivera GK, Pinkel D, Simone JV, Hancock ML, Crist WM. Treatment of acute lymphoblastic leukemia: 30 years' experience at St. Jude Children's Research Hospital. N Engl J Med 1993;329:1289-1295.

8. Steinherz PG, Gaynon P, Miller DR, et al. Improved disease-free survival of children with acute lymphoblastic leukemia at high risk for early relapse with the New York regimen -- a new intensive therapy protocol: a report from the Childrens Cancer Study Group. J Clin Oncol 1986;4:744-752. 
9. Miller DR, Leikin S, Albo V, Sather H, Karon M, Hammond D. Prognostic factors and therapy in acute lymphoblastic leukemia of childhood: CCG-141: a report from Childrens Cancer Study Group. Cancer 1983;51:1041-1049.

10. Gajjar A, Ribeiro R, Hancock ML, et al. Persistence of circulating blasts after 1 week of multiagent chemotherapy confers a poor prognosis in childhood acute lymphoblastic leukemia. Blood 1995;86:1292-1295.

11. Gaynon PS, Bleyer WA, Steinherz PG, et al. Day 7 marrow response and outcome for children with acute lymphoblastic leukemia and unfavorable presenting features. Med Pediatr Oncol 1990;18:273279.

12. Tubergen D, Gilchrist G, O'Brien RT, et al. Improved outcome with delayed intensification for children with acute lymphoblastic leukemia and intermediate presenting features: a Childrens Cancer Group phase III trial. J Clin Oncol 1993;11:527-537.

13. Pinkerton CR, Mills S, Chessells JM. Modified Capizzi maintenance regimen in children with relapsed acute lymphoblastic leukaemia. Med Pediatr Oncol 1986;14:69-72.

14. Nachman J, Sather HN, Gaynon PS, Lukens JN, Wolff L, Trigg ME. Augmented Berlin-Frankfurt-Munster therapy abrogates the adverse prognostic significance of slow early response to induction chemotherapy for children and adolescents with acute lymphoblastic leukemia and unfavorable presenting features: a report from the Children's Cancer Group. J Clin Oncol 1997;15:2222-2230.

15. Schrappe M, Reiter A, Riehm H. Cytoreduction and prognosis in childhood acute lymphoblastic leukemia. J Clin Oncol 1996;14:24032406.

16. Fleming T, Harrington D, O'Brien P. Designs for group sequential tests. Contemp Clin Trials 1958;53:457-81.

17. Kaplan E, Meier P. Nonparametric estimation from incomplete observations. J Am Stat Assoc 1958;53:457-81.

18. Mantel N. Evaluation of survival data and two new rank order statistics arising in its consideration. Cancer Chemother Rep 1966;50:163-170.

19. Peto $R$, Pike $M C$, Armitage $P$, et al. Design and analysis of randomized clinical trials requiring prolonged observation of each patient. II. Analysis and examples. Br J Cancer 1977;35:1-39.
20. Breslow N. Comparison of survival curves. In: Buyse M, Staquet MJ, Sylvester RJ, eds. Cancer clinical trials: methods and practice. Oxford, England: Oxford University Press, 1984:381-406.

21. Breslow N. Analysis of survival data under the proportional hazards model. Int Stat Rev 1975;43:45-58.

22. Steinherz PG, Gaynon PS, Breneman JC, et al. Cytoreduction and prognosis in acute lymphoblastic leukemia the importance of early marrow response: report from the Childrens Cancer Group. J Clin Oncol 1996;14:389-398.

23. Riehm H, Reiter A, Schrappe $M$, et al. Die Corticosteroid-abhängige Dezimierung der Leukamiezellzahl im Blut als Prognose faktor bei der akuten lymphoblastischen Leukämie im Kindesalter (Therapiestudie ALL-BMF 83). Klin Padiatr 1987;199:151-160.

24. Uckun F, Reaman G, Steinherz PG, et al. Improved clinical outcome for children with T-lineage acute lymphoblastic leukemia after contemporary chemotherapy: a Children's Cancer Group Study. Leuk Lymphoma 1996;24:57-70.

25. Aricò $M$, Schrappe $M$, Harbott J, et al. Prednisone good response (PGR) identifies a subset of $t(9 ; 22)$ childhood acute lymphoblastic leukemia (ALL) at lower risk for early leukemia relapse. Blood 1997;90:Suppl 1:560a-560a.

26. Tubergen DG, Gilchrist GS, O'Brien RT, et al. Prevention of CNS disease in intermediate-risk acute lymphoblastic leukemia: comparison of cranial radiation and intrathecal methotrexate and the importance of systemic therapy: a Childrens Cancer Group report. J Clin Oncol 1993;11:520-526.

27. Camitta B, Mahoney D, Leventhal B, et al. Intensive intravenous methotrexate and mercaptopurine treatment of higher-risk non-T, non-B acute lymphocytic leukemia: a Pediatric Oncology Group study. J Clin Oncol 1994;12:1383-1389.

28. Land VJ, Shuster JJ, Crist WM, et al. Comparison of two schedules of intermediate-dose methotrexate and cytarabine consolidation therapy for childhood B-precursor cell acute lymphoblastic leukemia: a Pediatric Oncology Group study. J Clin Oncol 1994;12:1939-1945. 